Biol. Stud. 2021; 15(3): 3-16 • DOI: https://doi.org/10.30970/sbi.1503.659

www.http://publications.Inu.edu.ua/journals/index.php/biology

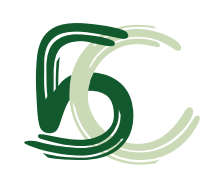

UDC: [612.1:599.323.4]:[615.8:615.252.349.7]

\title{
THE EFFECT OF PHOTOBIOMODULATION THERAPY ON SOME INDICES OF RATS' BLOOD CELLS FUNCTIONAL STATE UNDER EXPERIMENTAL DIABETES MELLITUS
}

\author{
O. I. Karmash®@, M. Ya. Liuta®, N. V. Yefimenko®, N. O. Sybirna® \\ Ivan Franko National University of Lviv, 4 Hrushevskyi St., Lviv 79005, Ukraine
}

Karmash, O.I., Liuta, M.Ya., Yefimenko, N.V., \& Sybirna, N.O. (2021). The effect of photobiomodulation therapy of some indices of rats' blood cells functional state under experimental diabetes mellitus. Studia Biologica, 15(3): 3-16 • DOI: https://doi.org/10.30970/sbi.1503.659

Background. Diabetes mellitus is a chronic endocrine-metabolic disease caused by an absolute or relative insulin deficiency. During diabetes, there are perfect conditions for the development of oxidative stress: the content of substrates for oxidation increases, the content of natural antioxidants decreases and the activity of antioxidant systems is suppressed. It is known that photobiomodulation therapy produce antioxidant and antihyperglycemic effects. Here we investigated its influence on blood system functioning.

Materials and Methods. The study was performed on male Wistar rats. Experimental diabetes mellitus was induced by the intraperitoneal injection of streptozotocin. Leukocyte formula was calculated using blood smears stained by RomanowskyGiemsa. Catalase activity was determined spectrophotometrically. Affinity of hemoglobin to oxygen was evaluated by spectrophotometric method in Ivanov's modification by drawing oxygenation curves. The protoporphyrin content in whole blood was measured by analyzing its fluorescence spectra. The content of $\mathrm{NO}_{2}^{-}$, total and inducible $\mathrm{NO}$ synthase activity was determined spectrophotometrically.

Results. Under the action of photobiomodulation therapy on healthy animals, there was a shift of oxygenation curves to the left and a decrease of $P_{50}$, whereas under irradiation of rats with diabetes, there was a shift of oxygenation curves to the right and increase in $\mathrm{P}_{50}$ compared to indices in nonirradiated animals. During diabetes, there was a decrease in protoporphyrin content compared to control, but there was a tendency to increase under photobiomodulation. Photobiomodulation therapy of rats with diabetes increased catalase activity in erythrocyte hemolysates. We revealed significant changes in leukocyte formula under photobiomodulation. The total NO synthase activity in leukocytes of rats with diabetes was higher compared to healthy animals, but decreased

(ㄷ 2021 О. I. Karmash et al. Published by the Ivan Franko National University of Lviv on behalf оf Біологічні Студії / Studia Biologica. This is an Open Access article distributed under the terms of the Creative Commons Attribution 4.0 License which permits unrestricted reuse, distribution, and reproduction in any medium, provided the original work is properly cited.

ISSN 1996-4536 (print) • ISSN 2311-0783 (on-line) • Біологічні Студії / Studia Biologica • 2021 • Том 15 / № 3 • С. 3-16 
under the action of photobiomodulation. We found an increase in inducible NO synthase activity in leukocytes of rats with diabetes and in leukocytes of irradiated healthy animals. An increase in $\mathrm{NO}_{2}^{-}$content in leukocytes of rats with diabetes was detected. Under photobiomodulation, $\mathrm{NO}_{2}{ }^{-}$content was significantly lower in rats with diabetes.

Conclusion. Photobiomodulation therapy produces a corrective action on blood system during diabetes, in particular, it improves oxygen release from hemoglobin and prevents hypoxia. Simultaneously with the increase in tissue oxygen saturation, a decrease in NO synthase activity and nitrite content along with an increase in catalase activity prevents the development of oxidative stress.

Keywords: diabetes mellitus, photobiomodulation therapy, hemoglobin, NO synthase

\section{INTRODUCTION}

Diabetes mellitus (DM), according to the definition of the World Health Organization experts, is a chronic endocrine-metabolic disease caused by an absolute (defects in synthesis) or relative (defects in action) insulin deficiency due to the action of different endogenous and exogenous factors accompanied by impairing in metabolism, especially carbohydrates. The most prominent manifestations of DM are hyperglycemia (persistent increase in blood glucose levels), lesions of various organs and tissues.

During diabetes, there are perfect conditions for the development of oxidative stress: the content of substrates for oxidation (glucose, lipids) increases, the content of natural antioxidants (glutathione, $\alpha$-tocopherol) decreases and the activity of antioxidant systems is suppressed [16]. During hyperglycemia accompanied by insulin resistance, there are a lot of metabolic mechanisms that activate and result in reactive oxygen species (ROS) production.

The first thing that is affected by hyperglycemia and excessive ROS is blood system. Changes in structure of erythrocyte membranes, impairment of oxygen binding to hemoglobin and modification of mechanical characteristics are the consequences of hyperglycemia action on erythrocytes. Excessive or insufficient functional activity of leukocytes leads to a higher susceptibility to infections in patients with DM. Patients with DM and acute coronary syndrome have a higher risk of cardiovascular complications and recurring ischemic occurrences compared to healthy people [22].

It is known that photobiomodulation therapy (PBM therapy) has antioxidant and antihyperglycemic effects [19]. We investigated the influence of PBM therapy on blood cells functioning by exploring oxygen-transport function of erythrocytes, their antioxidant status and also the state of L-arginine/NO system in leukocytes. We tested our hypothesis of protoporphyrin functioning as a primary chromophore for PBM therapy.

\section{MATERIALS AND METHODS}

The object of research. The study was performed on male Wistar rats weighing 130-180 g, which were kept in standard vivarium conditions with free access to food and water. Manipulations with animals were performed according to General Ethical Principles of Animal Experiments approved by the First National Congress for Bioethics (Kyiv, 2001), which agrees with the provisions of the European Convention for the Protection of Vertebrate Animals Used for Experimental and Other Scientific Purposes (Strasbourg, 1986).

ISSN 1996-4536 (print) • ISSN 2311-0783 (on-line) • Біологічні Студії / Studia Biologica • 2021 • Том 15 / № 3 • С. 3-16 
Induction of experimental diabetes mellitus (EDM). EDM was induced by intraperitoneal injection of streptozotocin ("Sigma", USA), diluted in $10 \mathrm{mM}$ Na-citrate buffer $(\mathrm{pH} 4.5)$ at the rate of $6 \mathrm{mg}$ of streptozotocin to $100 \mathrm{~g}$ of an animal's mass. The development of EDM was controlled by measuring fasting glucose concentration in blood $72 \mathrm{~h}$ after injection. Rats with blood glucose concentration above $12 \mathrm{mmol} / \mathrm{L}$ were used in the experiments.

Design of experiment. Animals were divided into 4 groups: 1 - control animals; 2 - irradiated control animals; 3 - animals with EDM; 4 - irradiated animals with EDM. 14 days after the induction of EDM, rats were exposed to PBM therapy for 5 min daily for 10 days with the installation "Device for conducting studies of optical radiation local effects on rats" (utility model patent No 78787 from 25.03.2013). The light source was matrix of 30 ultra-bright light-emitting diodes. Irradiation wavelength was $630-660 \mathrm{~nm}$ and a total power was $150 \mathrm{mWt}$, which is an analogue to Barva Fleks/FM photon matrices (Laser and Health Corporation, Ukraine).

Blood collection. After 10 days of irradiation, blood was collected by decapitation of animal using ether anesthesia. For preventing blood clotting samples were collected into the vials with heparin (final dilution heparin : whole blood $=1: 100$ ).

Isolation of rats' blood leukocytes. Leukocytes were isolated by fractional centrifugation in ficoll-triombrastum gradient $(\rho=1.076-1.078)$. The collected cells were washed twice by phosphate buffer saline (PBS: $(137 \mathrm{mM} \mathrm{NaCl}, 2.7 \mathrm{MM} \mathrm{KCl}, 10 \mathrm{mM}$ $\mathrm{Na}_{2} \mathrm{HPO}_{4} \times 7 \mathrm{H}_{2} \mathrm{O}, 1.8 \mathrm{MM} \mathrm{KH}_{2} \mathrm{PO}_{4}, \mathrm{pH} 7.4$ ) and immediately used in experiments or instantly frozen with liquid nitrogen and stored at $-20{ }^{\circ} \mathrm{C}$.

Leukocytes $\left(2 \times 10^{6}\right)$ were lyzed using $25 \mathrm{mM}$ Tris- $\mathrm{HCl}$ buffer $(\mathrm{pH} 7.5)$ containing $0.5 \%$ Triton X-100, $100 \mathrm{mM} \mathrm{KCl}, 5 \mathrm{MM} \mathrm{MgCl}_{2}, 2 \mathrm{mM} \mathrm{EDTA}$ and a cocktail of protease inhibitors ("Carl Roth GmbH+Co. KG", Germany, Art. No. 3751.1). Lysates were centrifuged for $15 \mathrm{~min}$ at $8000 \mathrm{rpm}$ and supernatant was used in the experiments.

Preparation of blood smears. Approximately $10-15 \mu \mathrm{L}$ of freshly collected blood was applied as a droplet on glass slide. Smear was made with a grounded glass, placed at $45^{\circ}$ to a glass slide. The obtained smears were dried and fixed in absolute methanol (for 3-5 min). Dried and fixed blood smears were stained by Romanowsky-Giemsa for 30-35 min, washed with water and dried. The Leukocyte formula of whole blood was calculated using a microscope.

Determining catalase activity (EC No. 1.11.1.6) [10]. The method is based on the ability of $\mathrm{H}_{2} \mathrm{O}_{2}$ to form a stable stained complex with molybdate salts.

$0.5 \mathrm{~mL} 0.05 \mathrm{M}$ Tris- $\mathrm{HCl}(\mathrm{pH} 7.8)$ and $1 \mathrm{~mL} 0.03 \% \mathrm{H}_{2} \mathrm{O}_{2}$ was added into vials. In the experimental vial, $50 \mu \mathrm{L}$ of sample was added. All vials were incubated for $10 \mathrm{~min}$ at $37{ }^{\circ} \mathrm{C}$ and after that $0.5 \mathrm{~mL}$ of $4 \%$ ammonium molybdate was added. After that we added $50 \mu \mathrm{L}$ of sample in blank vials and immediately measured the optical density at $\lambda=410$ using water as a blank. Catalase activity (in $\mu \mathrm{mol} \mathrm{H}_{2} \mathrm{O}_{2}$ per $1 \mathrm{~min} \times \mathrm{mg}$ of protein) was calculated by formula:

$$
A=\frac{\Delta E \cdot V \cdot n}{\varepsilon \cdot C \cdot t \cdot \alpha \cdot l},
$$

where $\Delta E$ is the difference in extinction between blank and experimental samples; $V$ total volume of mixture in cuvette, $\mathrm{mL} ; n$-dilution of initial sample; $\varepsilon$ - milimolar coefficient of extinction, $22.2 \mathrm{~cm}^{2} / \mu \mathrm{mol} ; C$ - protein concentration in the sample, $\mathrm{mg} / \mathrm{mL} ; t-$ time of reaction, $\min ; \alpha$-sample volume, $\mathrm{mL} ; \mathrm{I}-$ optical path length, $\mathrm{cm}$.

ISSN 1996-4536 (print) • ISSN 2311-0783 (on-line) • Біологічні Студії / Studia Biologica • 2021 • Том 15 / № 3 • С. 3-16 
Determination of hemoglobin affinity to oxygen $[1 ; 7]$. The affinity of hemoglobin to oxygen was evaluated by spectrophotometric method in Ivanov's modification by drawing oxygenation curves.

Erythrocytes were hemolyzed by $3.3 \mathrm{mM} \mathrm{K} / \mathrm{Na}^{+}$-phosphate buffer ( $\mathrm{pH}$ 7.36). The experiments were conducted using hemoglobin solution with optical density before deoxygenation $0.400-0.500$ at wavelength $560 \mathrm{~nm}$ that is equal to concentration $4.5-5.0 \times 10^{-5} \mathrm{M}$.

The device (saturator) consists of a tonometer and a system of dosing and exchange of gas components, was used for the experiments.

The cuvette was filled with $4 \mathrm{~mL}$ of hemoglobin solution. To avoid rapid foaming of the solution when pumping air, the cuvette was placed in chilled water. For better deoxygenation, the cuvette was gradually heated to $37^{\circ} \mathrm{C}$.

The degree of hemoglobin conversion into deoxy form was controlled spectrophotometrically using the approximate criterion of complete hemoglobin deoxygenation $D_{555} / D_{540} \geq 1.24$, where $D$ - optical density of solution.

Optical density of deoxyhemoglobin solution was measured at wavelength $\lambda=558 \mathrm{~nm}$. Partial pressure of oxygen was increased by adding dosed portions of air. After thermostating for $5 \mathrm{~min}$, optical density of the solution was measured. 6-8 measurements were registered and based on these results, curves of hemoglobin dissociation, i.e. curves of dependence of hemoglobin saturation with oxygen (\%) from partial pressure of oxygen $\left(\mathrm{mm} \mathrm{Hg}\right.$ ) were drawn. From these curves, $P_{50}$ index was calculated. $P_{50}$ is the main index that was used to determine affinity of hemoglobin to oxygen.

Determination of protoporphyrin content [21]. To $0.2 \mathrm{~mL}$ of distilled water, $0.05 \mathrm{~mL}$ of whole blood was added. After thorough mixing, $0.05 \mathrm{~mL}$ of the obtained hemolysate was added to $1 \mathrm{~mL}$ of ethylacetate-glacial acetic acid mixture ( $4: 1$ by volume), mixed and centrifuged for $3 \mathrm{~min}$ at $3000 \mathrm{rpm}$. The obtained supernatant was decanted and added to $1 \mathrm{~mL}$ of $1.5 \mathrm{M} \mathrm{HCl}$. The solution was mixed and centrifuged for $1 \mathrm{~min}$ at $3000 \mathrm{rpm}$. Two distinctive liquid phases were obtained: ethylacetate (brown) and $\mathrm{HCl}$ (transparent). Using spectrofluorometer Shimadzu RF-6000, fluorescence spectra of transparent phase was measured at excitation wavelength of $408 \mathrm{~nm}$ and emission wavelengths of 645-680 nm. Using software LabSolutions RF ver. 1.15 area under the peak at $662 \mathrm{~nm}$ was measured. Protoporphyrin content was expressed as AU per $1 \mu \mathrm{L}$ of blood.

Determination of nitrite anion $\left(\mathrm{NO}_{2}^{-}\right)$content [15]. The content of nitrite anion was determined in samples of leukocyte lysates. Deproteinization was performed by adding $96 \%$ ethanol to samples with next centrifuging for $20 \mathrm{~min}$ at $5000 \mathrm{rpm}$ at $20^{\circ} \mathrm{C} .100 \mu \mathrm{L}$ of the obtained supernatant and $100 \mu \mathrm{L}$ of Griess reagent (0.05\% N (1-naphthyl)-ethylenediamine and $1 \%$ sulphanilamide in $12 \%$ acetic acid in proportion $1: 1$ ) were added into microplate vials. The blank vial instead of the sample contained $100 \mu \mathrm{L}$ of distilled water. Vials were incubated for $30 \mathrm{~min}$ at $37^{\circ} \mathrm{C}$ and optical density at wavelength $\lambda=540 \mathrm{~nm}$ was measured. The result was calculated by means of a calibration curve that was drawn using standard solutions of sodium nitrite.

Determination of total and inducible NO synthase (NOS) activity [15; 2]. At determining total $\mathrm{NO}$ synthase activity. $10 \mathrm{mM}$ of HEPES buffer, containing $1 \mathrm{M} \mathrm{MgCl}_{2}, 1 \mathrm{M} \mathrm{CaCl}_{2}$, $3 \mathrm{mM} \mathrm{L}$-arginine and $0.1 \mathrm{mM} \mathrm{NADPH}\left(\mathrm{H}^{+}\right)$was added to the obtained supernatant of leukocytes lysate. Samples containing full substrate mixture and $\mathrm{H}_{2} \mathrm{O}$ were used as blank. After 30 min incubation of the samples at $37^{\circ} \mathrm{C}$ the reaction was stopped by addition of $96 \%$ ethanol in 1:4 proportion. The samples were centrifuged for $20 \mathrm{~min}$ at $3000 \mathrm{rpm}$.

ISSN 1996-4536 (print) • ISSN 2311-0783 (on-line) • Біологічні Студії / Studia Biologica • 2021 • Том 15 / № 3 • С. 3-16 
$100 \mu \mathrm{L}$ of the obtained supernatant and $100 \mu \mathrm{L}$ of Griess reagent were added into microplate vials, the mixture was incubated for $30 \mathrm{~min}$ at $37^{\circ} \mathrm{C}$ and optical density at wavelength $\lambda=540 \mathrm{~nm}$ was measured. Total $\mathrm{NO}$ synthase activity was expressed as nmol of newly formed $\mathrm{NO}_{2}^{-}$for 1 min per $1 \mathrm{mg}$ of protein.

Determination of inducible NO synthase activity. The method is similar to abovementioned but for determining $\mathrm{Ca}^{2+}$-independent NOS activity EDTA was added to the incubation mixture instead of $\mathrm{CaCl}_{2}$.

Statistical analysis of results. Statistical analysis of results was carried out using Microsoft Excel 2016 program. The calculation of the main statistical indicators was performed based on direct quantitative data (arithmetic mean value - M; standard error of the arithmetic mean $-m$ ). The difference between indices was evaluated using Student criteria. The difference was considered significant at $p \geq 0.95$ (level of significance $P<0.05$ ).

\section{RESULTS AND DISCUSSION}

Peripheral blood is the system that reflects the state of the whole organism as it is affected by the action of factors that provoke the development of pathology of any etiology. Most often, in pathological conditions there are impairments in oxygen transport function of erythrocytes and immune system disorders, for which leukocytes are responsible.

Hemoglobin is the main protein in erythrocytes. This complex protein contains prosthetic group - heme. Heme is the complex of protoporphyrin IX that belongs to the class of porphyrin compounds with iron (II) atom. Such a colored compound as hemoglobin could be a good candidate for the role of a chromophore in blood for PBM therapy.

Curve of oxyhemoglobin dissociation (COD) reflects saturation of hemoglobin with oxygen (y-axis) as a function from oxygen partial pressure (x-axis). Sigmoid or S-form of the curve is caused by positive cooperation of hemoglobin [18]. An important index of the level of hemoglobin oxygen affinity is $\mathrm{P}_{50}-\mathrm{pO}_{2}$ value at which hemoglobin releases $50 \%$ of bound oxygen. As a result of our research, it was revealed that during EDM there is a shift of COD to the left and a 1.4-fold decrease in $\mathrm{P}_{50}$ compared to control (Table 1).

\section{Table 1. $\quad \mathbf{P}_{50}$ values under the studied conditions $(\mathrm{mm} \mathrm{Hg})$}

Таблиця 1. Значення $\mathbf{P}_{50}$ за досліджуваних умов (мм рт. ст.)

\begin{tabular}{c|c}
\hline Group of animals & $\mathrm{P}_{50},(\mathrm{M} \pm \mathrm{m})$ \\
\hline Control & $26.29 \pm 2.68$ \\
\hline Control + PBM & $20.00 \pm 1.61^{*}$ \\
\hline EDM & $18.71 \pm 1.05^{\star}$ \\
\hline EDM + PBM & $21.75 \pm 1.06^{\#}$ \\
\hline
\end{tabular}

Comments: * - significant difference compared with the control, $\mathrm{P}<0.05$; ${ }^{*}$ - significant difference compared with EDM, $\mathrm{P}<0.05$

Примітки: * різниця вірогідна порівняно з контролем, $\mathrm{P}<0,05$; * різниця вірогідна порівняно з ЦД, $P<0,05$

The shift of COD to the left indicates the development of hypoxia state in an organism. The increase in methemoglobin and glycosylated hemoglobin content during EDM contributes to an increase in hemoglobin affinity to oxygen. This prevents allosteric regulation of oxygen transport function of oxyhemoglobin involving 2,3-diphosphoglycerate.

ISSN 1996-4536 (print) • ISSN 2311-0783 (on-line) • Біологічні Студії / Studia Biologica • 2021 • Том 15 / № 3 • C. 3-16 
During PBM therapy of healthy animals, there was a shift of COD to the left and a 1.31-fold decrease in $P_{50}$, whereas during irradiation of animals with EDM, there was a shift of COD to the right and a 1.16-fold increase in $P_{50}$ compared to indices in the nonirradiated animals (Fig. 1).

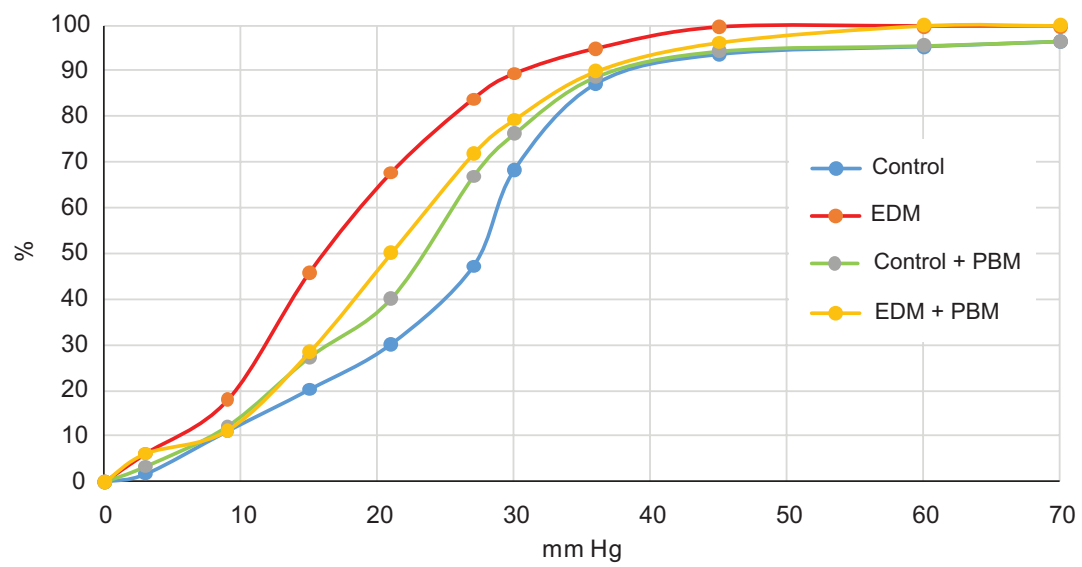

Fig. 1. Typical curves of oxyhemoglobin dissociation in rats under studied conditions.

Рис. 1. Типові криві дисоціації оксигемоглобіну щурів за досліджуваних умов

Absorption spectra of hemoglobin and oxyhemoglobin have the biggest interval at wavelengths between 630 and $670 \mathrm{~nm}$. It is possible that PBM therapy by these wavelengths improves the ability of the blood to transport oxygen [25]. When analyzing the effect of low-intensity irradiation of different wavelengths on the absorption spectra of blood and hemoglobin, it was found that lasers with wavelengths 200-240, 275 and $342 \mathrm{~nm}$ easily ruin protein molecules leading to the loss of hemoglobin biological function. While lasers with wavelengths above $800 \mathrm{~nm}$ decrease the ability of blood to transport oxygen, lasers with wavelengths from 630 to $670 \mathrm{~nm}$ have the best efficiency [24].

Besides, in our previous researches [9], we revealed that during PBM therapy of rats with EDM there was a decrease in glycosylated hemoglobin concentration, which is known for higher affinity to oxygen.

An increase in $\mathrm{P}_{50}$ was caused by photodissociation of oxyhemoglobin with releasing of oxygen and converting of hemoglobin to deoxyhemoglobin. Therefore, the local concentration of free molecular oxygen in the tissues can be controlled. An additional release of oxygen prevents the development of tissue hypoxia and stimulates aerobic metabolism of cells.

We studied the precursor substance in the synthesis of heme - protoporphyrin IX (PPIX), because contrary to hemoglobin, protoporphyrin can be transported from the cells to the outside, where it can act as a chromophore for PBM therapy [20].

According to the absorption spectra available in the literature, protoporphyrin has one of the absorption peaks at $630 \mathrm{~nm}$ that coincides with irradiation spectra of our device [12]. Thus, protoporphyrin can act as a primary acceptor of light energy for PBM therapy. In the previous research, we revealed that during PBM therapy there was an increase in hemoglobin content in healthy animals and rats with EDM [9].

It was found that during PBM therapy protoporphyrin content decreased 1.3-fold compared to control. There is also a tendency for this index to increase during irradiation 
of rats with EDM (Fig. 2). This fact can be explained by a general hypoglycemic activity of PBM therapy as it is known that hyperglycemia in blood inhibits ALAS enzyme activity, which is involved in the process of heme biosynthesis [6].

Fig. 2. Protoporphyrin content in whole blood, AU/ $\mu \mathrm{L} .{ }^{*}-$ significant difference compared with the control, $P<0.05 ;{ }^{\#}-$ significant difference compared with EDM, $\mathrm{P}<0.05$

Рис. 2. Вміст протопорфірину в цільній крові, АU/мкл. * - різниця вірогідна порівняно 3 контролем, $\mathrm{P}<0,05 ;{ }^{*}-$ різниця вірогідна порівняно з ЦД, $\mathrm{P}<0,05$

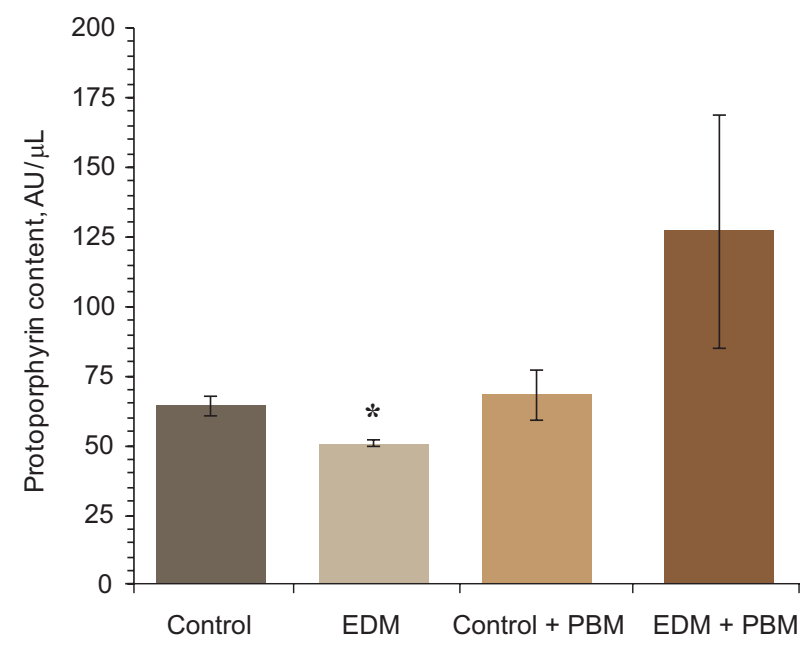

We revealed that during EDM there was a 1.48-fold decrease in catalase activity in erythrocytes. However, PBM therapy treatment of rats with EDM caused a 1.43-fold increase in this index compared to nontreated animals with EDM (Fig. 3). In our previous research, we revealed similar results for catalase and superoxide dismutase activity in leukocyte lysates [8]. We concluded that positive effects of PBM therapy occured not because of its influence on protoporphyrin, as we did not find significant changes in protoporphyrin content under irradiation. It is possible that PBM therapy acts due to an influence on pro-/antioxidant balance in cell or by lowering glucose level in blood.

Fig. 3. Catalase activity in erythrocytes hemolysates, $\mu \mathrm{mol} \mathrm{H}_{2} \mathrm{O}_{2} / \mathrm{min} \times \mathrm{mg}$ of protein. * - significant difference compared with the control, $\mathrm{P}<0.05$; * significant difference compared with EDM, $\mathrm{P}<0.05$

Рис. 3. Активність каталази у гемолізатах еритроцитів, мкмоль $\mathrm{H}_{2} \mathrm{O}_{2} /$ хв $\times$ мг білка. * - різниця вірогідна порівняно з контролем, Р < 0,05; \# - різниця вірогідна порівняно з ЦД, $Р<0,05$

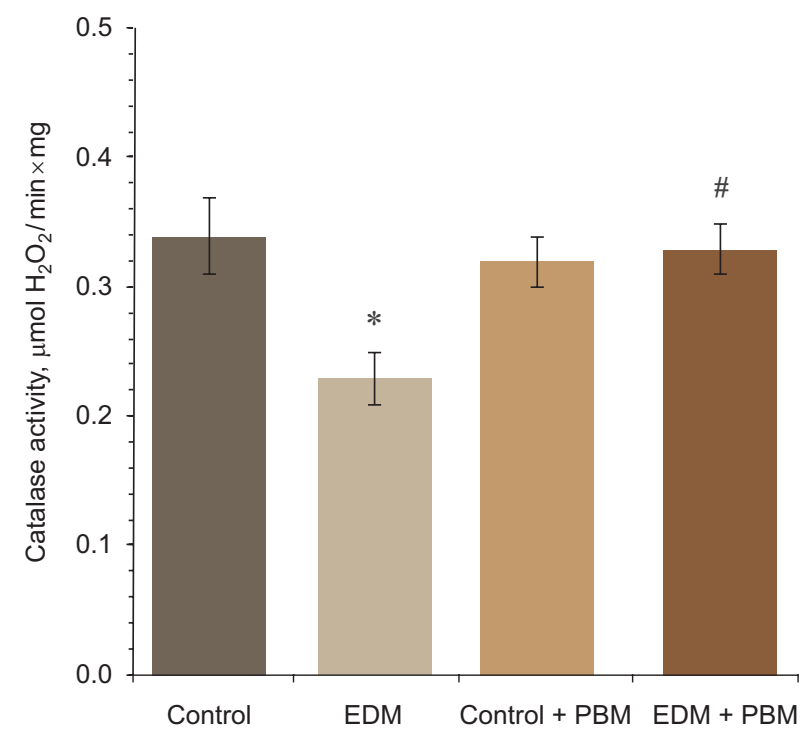

ISSN 1996-4536 (print) • ISSN 2311-0783 (on-line) • Біологічні Студії / Studia Biologica • 2021 • Том 15 / № 3 • C. 3-16 
To investigate the effect of PBM therapy on blood system in more detail, we examined the composition of the leukocyte blood formula under the studied conditions. We revealed a significant increase in segmentonuclear neutrophils number (1.23 times) and a decrease in lymphocytes number (1.05 times) in PBM treated rats with EDM (Table 2). These results can indicate the intensification of the innate immune system and, more importantly, a potential activation of oxidative-nitrative stress development as neutrophil granulocytes can produce a big amount of ROS in response to stimulation.

Table 2. Leukocyte formula of blood, \%

Таблиця 2. Лейкоцитарна формула крові, \%

\begin{tabular}{|c|c|c|c|c|}
\hline \multirow{2}{*}{ Cell types $\quad$ Groups of animals } & Control & EDM & Control + PBM & EDM + PBM \\
\hline & $M \pm m$ & $\mathrm{M} \pm \mathrm{m}$ & $\mathrm{M} \pm \mathrm{m}$ & $\mathrm{M} \pm \mathrm{m}$ \\
\hline Band neutrophils & $1.00 \pm 0.63$ & $1.36 \pm 0.26$ & $1.13 \pm 0.41$ & $1.65 \pm 0.46$ \\
\hline Segmented neutrophils & $17.90 \pm 1.40$ & $15.81 \pm 1.77$ & $18.43 \pm 2.48$ & $22.03 \pm 1.76^{*}$ \\
\hline Lymphocytes & $73.14 \pm 0.82$ & $75.48 \pm 1.40$ & $74.82 \pm 2.20$ & $69.63 \pm 1.56^{*}$ \\
\hline Eosinophils & $2.40 \pm 0.37$ & $3.23 \pm 0.46$ & $1.73 \pm 0.56$ & $2.20 \pm 0.28$ \\
\hline Monocytes & $5.58 \pm 0.69$ & $4.10 \pm 0.53$ & $3.20 \pm 0.41$ & $4.45 \pm 0.56$ \\
\hline Basophils & $0.00 \pm 0.00$ & $0.06 \pm 0.06$ & $0.75 \pm 0.75$ & $0.05 \pm 0.05$ \\
\hline
\end{tabular}

Comments: * - significant difference compared with the control, $\mathrm{P}<0.05$; ${ }^{*}$ - significant difference compared with EDM, $\mathrm{P}<0.05$

Примітки: * - різниця вірогідна порівняно з контролем, $\mathrm{P}<0,05$; ${ }^{-}$- різниця вірогідна порівняно з ЦД, $P<0,05$

In this study, we paied attention to the nitrative part of oxidative-nitrative stress system, namely NO synthase activity and nitrite content.

As a result of our research, we found that total NOS activity in leukocytes of rats with EDM was 2.48 times higher compared to healthy animals. Instead, PBM therapy caused a 2.5-fold decrease in total NOS activity in leukocytes of rats with EDM compared to nontreated rats with EDM (Fig. 4). Besides, we revealed a 2.02-fold increase in inducible NOS (iNOS) activity in leukocytes of animals with EDM compared to the control group. PBM therapy treatment of healthy animals also caused a 1.45-fold increase in iNOS in leukocytes. PBM therapy had no significant effect on iNOS activity in leukocytes of rats with EDM but there was a tendency for this index to decrease (Fig. 5).

One of the consequences of oxidative-nitrative stress that develops during diabetes is an increase in lipid peroxidation (LPO) in cell and mitochondrial membranes leading to the suppression of active $\mathrm{Ca}^{2+}$ transport and to an increase in membrane permeability to $\mathrm{Ca}^{2+}$ [13]. It is known that chronic hyperglycemia leads to an increase in endothelial NOS expression [5]. $\mathrm{Ca}^{2+}$ ions become the reason of endothelial and neuronal NOS activation by binding of calcium-calmodulin to region (30 amino acid-long) that connects oxygenase and reductase domains of subunits [23]. One of the reasons for the decrease in total NOS activity may be an increased activity of antioxidant enzymes that results in a suppressed production of superoxide-anion radical $\left({ }^{\circ} \mathrm{O}^{2-}\right)$ and diminished LPO. LPO suppressing leads to a decreased permeability of membranes to $\mathrm{Ca}^{2+}$ ions and restoring of their active transport in ER and mitochondria. The other reason may be a competition for the substrate (L-arginine) with iNOS that have an increased activity due to PBM therapy.

ISSN 1996-4536 (print) •ISSN 2311-0783 (on-line) • Біологічні Студії / Studia Biologica • 2021 • Том 15 / № 3 • C. 3-16 
Fig. 4. Total NOS activity in leukocytes lysates, $\mathrm{nmol} \mathrm{NO}_{2}^{-} \times \mathrm{min} / \mathrm{mg}$ of protein. * - significant difference compared with the control, $\mathrm{P}<0.05$; \# - significant difference compared with EDM, $\mathrm{P}<0.05$

Рис. 4 Сумарна активність NOS у лізатах лейкоцитів, нмоль $\mathrm{NO}_{2}^{-} \times$хв/ мг білка. * - різниця вірогідна порівняно з контролем, $\mathrm{P}<0,05$; \# - різниця вірогідна порівняно з ЦД, $\mathrm{P}<0,05$

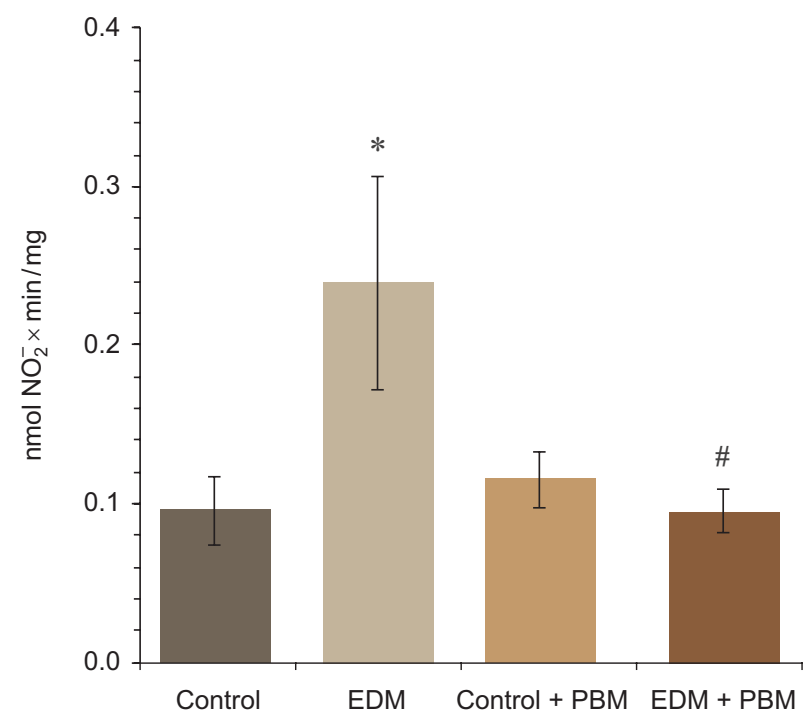

Fig. 5. iNOS activity in leukocytes lysates, $\mathrm{nmol} \mathrm{NO}_{2}^{-} \times \mathrm{min} / \mathrm{mg}$ of protein. ${ }^{*}-$ significant difference compared with the control, $\mathrm{P}<0.05$; \# - significant difference compared with EDM, $\mathrm{P}<0.05$

Рис. 5. Активність iNOS у лізатах лейкоцитів, нмоль $\mathrm{NO}_{2}^{-} \times$хв/мг білка. * - різниця вірогідна порівняно з контролем, $\mathrm{P}<0,05$; ${ }^{-}$різниця вірогідна порівняно з ЦД, Р < 0,05

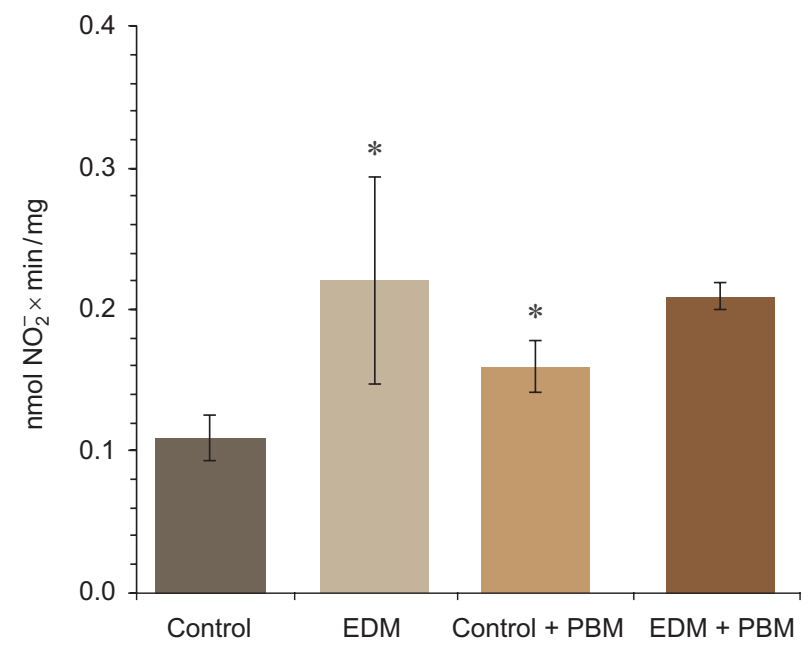

As mentioned above, the development of oxidative-nitrative stress becomes the reason for an increased $\mathrm{Ca}^{2+}$ concentration in cytoplasm. $\mathrm{Ca}^{2+}$ ions activate intracellular processes, in particular assembling of NADPH oxidase complex on the membrane. This is caused by an increased production of ${ }^{\circ} \mathrm{O}_{2}^{-}$that, in turn, becomes the reason for an elevated biosynthesis of NO by iNOS and enhanced LPO leading to an increased permeability of membranes to $\mathrm{Ca}^{2+}$ [14]. Nitric oxide produced in mitochondria can inhibit cellular respiration by binding with cytochrome c oxidase and displacing of oxygen. It is known that PBM therapy can cause releasing of NO from cytochrome c oxidase and, in such a way, restoring mitochondrial respiration [3].

Availability of NO synthase mechanism ensures endogenous synthesis of NO which is eventually oxidized to nitrites and nitrates. Thus, the increase in total NOS and iNOS activity in animals with EDM and in the irradiated control group of rats can be the reason for an increased nitrite level in leukocytes.

ISSN 1996-4536 (print) • ISSN 2311-0783 (on-line) • Біологічні Студії / Studia Biologica • 2021 • Том 15 / № 3 • С. 3-16 
Indeed, we revealed a 1.92-fold increase in $\mathrm{NO}_{2}^{-}$in leukocyte lysates of rats with EDM compared to control. Under the PBM therapy treatment, $\mathrm{NO}_{2}^{-}$content in rats with EDM was significantly (1.47 times) lower than in nonirradiated animals with EDM (Fig. 6).

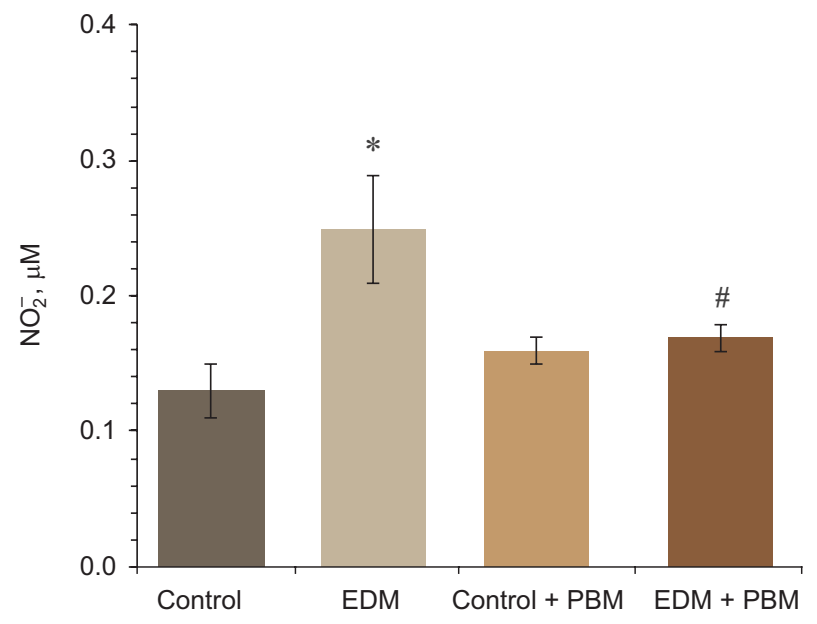

Fig. 6. $\mathrm{NO}_{2}^{-}$content in leukocytes lysates, $\mu \mathrm{M} .{ }^{*}$ - significant difference compared with the control, $\mathrm{P}<0.05$ \# - significant difference compared with EDM, $\mathrm{P}<0.05$

Рис. 6. Вміст $\mathrm{NO}_{2}^{-}$у лізатах лейкоцитів, мкмоль. * - різниця вірогідна порівняно з контролем, $\mathrm{P}<0,05$; \# - різниця вірогідна порівняно з ЦД, Р $<0,05$

It is known that ROS production in leukocytes is accompanied by an increased consumption of oxygen that is necessary for further conversion of nitrites to nitrates. At the same time, the interaction of $\mathrm{NO}$ with $\mathrm{O}_{2}{ }^{-}$leads to the formation of a highly toxic compound - peroxynitrite, one of the decay products of which are nitrite ion and hydroxyl radical [17]. It is also known that in conditions of oxygen deficit endothelial NOS can manifest nitrite reductase activity generating NO [4; 11]. As mentioned above, the consequence of PBM therapy treatment of rats with EDM is the increase in catalase and superoxide dismutase activity. This results in a decrease in peroxynitrite and ${ }^{\circ} \mathrm{O}_{2}^{-}$production and also in an increase in $\mathrm{O}_{2}$ concentration that causes the decrease in $\mathrm{NO}$ and $\mathrm{NO}_{2}{ }^{-}$content.

\section{CONCLUSION}

Based on the results of our study, conclusions can be drawn that PBM therapy has a positive corrective effect on blood system during EDM, in particular it improves the release of oxygen from hemoglobin molecules and prevents hypoxia. Simultaneously with an increase in tissue oxygen saturation, a decrease in NOS activity and nitrite content along with an increase in catalase activity prevent oxidative-nitrative stress. We consider appropriate and promising further research on molecular and biochemical mechanisms of PBM therapy effects on the blood system and the whole organism and on possibilities of using phototherapeutic devices as non-pharmacological and non-invasive methods of treatment (adjuvant therapy) for patients with diabetes mellitus.

\section{ACKNOWLEDGMENTS AND FUNDING SOURCES}

This study did not receive any particular grant from any financial organizations in the state, commercial, or noncommercial sectors.

ISSN 1996-4536 (print) • ISSN 2311-0783 (on-line) • Біологічні Студії / Studia Biologica • 2021 • Том 15 / № 3 • С. 3-16 


\section{COMPLIANCE WITH ETHICAL STANDARDS}

Conflict of Interest: The authors declare that the research was conducted in the absence of any commercial or financial relationships that could be construed as a potential conflict of interest.

Human Rights: This article does not contain any studies with human subjects performed by any of the authors.

Animal studies: All international, national and institutional guidelines for the care and use of laboratory animals were followed.

\section{AUTHOR CONTRIBUTIONS}

Conceptualization, [S.N.O.]; methodology, [K.O.I.; L.M.Ya.; Y.N.V.]; validation, [S.N.O.; K.O.I.]; formal analysis, [K.O.I.; L.M.Ya.; Y.N.V.].; investigation, [K.O.I.; L.M.Ya.; Y.N.V.]; resources, [S.N.O.; K.O.I.; L.M.Ya.; Y.N.V.]; data curation, [K.O.I.; L.M.Ya.;Y.N.V.]; writing - original draft preparation, [K.O.I.]; writing - review and editing, [S.N.O.]; visualization, [K.O.I.]; supervision, [S.N.O.]; project administration, [S.N.O.]; funding acquisition, [-].

All authors have read and agreed to the published version of the manuscript.

1. Benesch, R., Macduff, G., \& Benesch, R. E. (1965). Determination of oxygen equilibria with a versatile new tonometer. Analytical Biochemistry, 11(1), 81-87.

Crossref $\bullet$ PubMed $\bullet$ Google Scholar

2. Dawson, J., \& Knowles, R.G. (1998). A microtiter-plate assay of human NOS isoforms. Methods in molecular biology (Clifton, N.J.), 100, 237-242.

Crossref $\bullet$ PubMed $\bullet$ Google Scholar

3. De Freitas, L.F., \& Hamblin, M.R. (2016). Proposed Mechanisms of Photobiomodulation or Low-Level Light Therapy. IEEE Journal of Selected Topics in Quantum Electronics, 22(3), 348-364.

Crossref $\bullet$ PubMed $\bullet$ PMC $\bullet$ Google Scholar

4. Drel, V.R. (2010). Main mechanisms of the initiation and development of diabetic complications: the role of nitrative stress. Studia Biologica, 4(2), 141-158. [In Ukrainian] Crossref $\bullet$ Google Scholar

5. Gancheva, O.V., Kolesnyk, Y.M., \& Vorodeeva, Y.I. (2016). Pathogenetical linkage of the Nitric oxide synthase isoforms disbalance in pancreatic islets with chronical prenatal hyperglycemia. Zaporozhye Medical Journal, 1(94), 35-39. [In Ukrainian]

Crossref • Google Scholar

6. Handschin, C., Lin, J., Rhee, J., Peyer, A.K., Chin, S., Wu, P.H., Meyer, U.A., \& Spiegelman, B.M. (2005). Nutritional regulation of hepatic heme biosynthesis and porphyria through PGC-1a. Cell, 122(4), 505-515.

Crossref • PubMed $\bullet$ Google Scholar

7. Ivanov, Y.G. (1975). Modification of the spectrophotometric method for determining the oxygen-dissociation curves of hemoglobin. Bulletin of Experimental Biology and Medicine, 80, 1399-1400. [In Russian]

Crossref $\bullet$ Google Scholar

8. Karmash, O.I., Liuta, M.Y., Korobov, A.M., \& Sybirna, N.O. (2020). Effect of photomodulation therapy on development of oxidative stress in blood leukocytes of rats with streptozocininduced diabetes mellitus. Cytology and Genetics, 54(5), 456-464.

Crossref $\bullet$ Google Scholar

ISSN 1996-4536 (print) • ISSN 2311-0783 (on-line) • Біологічні Студії / Studia Biologica • 2021 • Том 15 / № 3 • С. 3-16 
9. Karmash, O.I., Liuta, M.Y., Yefimenko, N.V., Korobov, A.M., \& Sybirna, N.O. (2018). The influence of low-level light radiation of red spectrum diapason on glycemic profile and physicochemical characteristics of rat's erythrocytes in diabetes mellitus. Fiziolohichny̆ Zhurnal, 64(6), 68-76. [In Ukrainian]

Crossref $\bullet$ Google Scholar

10. Koroliuk, M.A., Ivanova, L.I., Maĭorova, I.G., \& Tokarev, V.E. (1988). Metod opredeleniia aktivnosti katalazy [A method of determining catalase activity]. Laboratornoe delo, (1), 16-19. [In Russian]

PubMed • Google Scholar

11. Kovalenko, O.V., \& Kostenko, V.O. (2011). NO-dependent changes in lipid peroxidation processes and antioxidant protection in tissues of undermandibular salivary glands durinf recreation of traumatic sialoadenitis. Visnik problem biologiï i medicini, 4(90): 106-110. [In Ukrainian] Google Scholar

12. Lim, C.K., Razzaque, M.A., Luo, J., \& Farmer, P.B. (2000). Isolation and characterization of protoporphyrin glycoconjugates from rat Harderian gland by HPLC, capillary electrophoresis and HPLC/electrospray ionization MS. Biochemical Journal, 347(3), 757-761.

Crossref $\bullet$ PubMed $\bullet$ PMC $\bullet$ Google Scholar

13. Lytvynets, Ye.A., \& Hotsulyak, Ya.V. (2012). Peroxidation condition of lipids and antioxidant protection in the pathology of urine system and the expediency of using bioflavonoids in the complex treatment. Health of man, (1), 135-137. [In Ukrainian]

Google Scholar

14. Millana Fañanás, E., Todesca, S., Sicorello, A., Masino, L., Pompach, P., Magnani, F., Pastore, A., \& Mattevi, A. (2020). On the mechanism of calcium-dependent activation of NADPH oxidase 5 (NOX5). The FEBS journal, 287(12), 2486-2503.

Crossref $\bullet$ PubMed $\bullet$ PMC $\bullet$ Google Scholar

15. Miranda, K.M., Espey, M.G., \& Wink, D.A. (2001). A rapid, simple spectrophotometric method for simultaneous detection of nitrate and nitrite. Nitric Oxide, 5(1), 62-71.

Crossref $\bullet$ PubMed $\bullet$ Google Scholar

16. Mokryi, V.Y., Ziablitsev, S.V., \& Borys, R.M. (2015). Violations of the system of lipid peroxidation in type 2 diabetes mellitus (Literature Review). International Journal of Endocrinology, 7(71), 41-44. [In Ukrainian]

Crossref • Google Scholar

17. Mungrue, I.N., Husain, M., \& Stewart, D.J. (2002). The role of NOS in heart failure: lessons from murine genetic models. Heart failure reviews, 7(4), 407-422.

Crossref $\bullet$ PubMed $\bullet$ Google Scholar

18. Patel, S., Jose, A., \& Mohiuddin, S.S. (2021). Physiology, Oxygen Transport And Carbon Dioxide Dissociation Curve. In StatPearls. StatPearls Publishing.

PubMed • Google Scholar

19. Ribeiro, B.G., Alves, A.N., Dos Santos, L.A., Cantero, T.M., Fernandes, K.P., Dias, D., Bernardes, N., De Angelis, K., \& Mesquita-Ferrari, R.A. (2016). Red and infrared low-level laser therapy prior to injury with or without administration after injury modulate oxidative stress during the muscle repair process. PloS One, 11(4), e0153618.

Crossref $\bullet$ PubMed $\bullet$ PMC $\bullet$ Google Scholar

20. Sachar, M., Anderson, K.E., \& Ma, X. (2015). Protoporphyrin IX: the Good, the Bad, and the Ugly. Journal of Pharmacology and Experimental Therapeutics, 356(2), 267-275.

Crossref $\bullet$ PubMed $\bullet$ PMC $\bullet$ Google Scholar

21. Sassa, S., Granick, J.L., Granick, S., Kappas, A., \& Levere, R.D. (1973). Studies in lead poisoning. I. Microanalysis of erythrocyte protoporphyrin levels by spectrophotometry in the detection of chronic lead intoxication in the subclinical range. Biochemical Medicine, 8(1), 135-148.

Crossref $\bullet$ PubMed $\bullet$ Google Scholar

ISSN 1996-4536 (print) •ISSN 2311-0783 (on-line) • Біологічні Студії / Studia Biologica • 2021 • Том 15 / № 3 • C. 3-16 
22. Szablewski, L., \& Sulima, A. (2017). The structural and functional changes of blood cells and molecular components in diabetes mellitus. Biological Chemistry, 398(4), 411-423. Crossref $\bullet$ PubMed $\bullet$ Google Scholar

23. Voet, D., \& Voet, J.G. (2011). Biochemistry (4th ed.). USA: John Wiley \& Sons.

24. Xu, Y., Lin, Y., \& Gao, S. (2015). Study on the selection of laser wavelengths in the intravascular low-level laser irradiation therapy. Lasers in Medical Science, 30(4), 1373-1376. Crossref $\bullet$ PubMed $\bullet$ Google Scholar

25. Xu, Y., Lin, Y., Gao, S., \& Shen, J. (2018). Study on mechanism of release oxygen by photoexcited hemoglobin in low-level laser therapy. Lasers in Medical Science, 33(1), 135-139. Crossref $\bullet$ PubMed $\bullet$ Google Scholar

\section{ВПЛИВ ФОТОБІОМОДУЛЯЦІЙНОЇ ТЕРАПІЇ НА ОКРЕМІ ПОКАЗНИКИ ФУНКЦІОНАЛЬНОГО СТАНУ КЛІТИН КРОВІ ЩУРІВ ЗА УМОВ ЕКСПЕРИМЕНТАЛЬНОГО ЦУКРОВОГО ДІАБЕТУ}

\section{О. І. Кармаш, М. Я. Люта, Н. В. Єфіменко, Н. О. Сибірна Львівський національний університет імені Івана Франка вул. Грушевського, 4, Львів 79005, Україна}

Вступ. Цукровий діабет - це хронічне ендокринно-обмінне захворювання, яке зумовлене абсолютною або відносною недостатністю інсуліну. За діабету виникають ідеальні умови для розвитку оксидативного стресу: збільшується вміст субстратів окиснення, зменшується вміст природних антиоксидантів, а також знижується активність антиоксидантних систем. Відомо, що фотобіомодуляційна терапія має антиоксидантні й антигіперглікемічні ефекти, тому ми вирішили дослідити її вплив на функціонування системи крові.

Матеріали та методи. Дослідження проводили на самцях щурів лінії Wistar. Експериментальний цукровий діабет індукували внутрішньоочеревинним введенням стрептозотоцину. Лейкоцитарну формулу підраховували на мазках цільної крові, зафарбованих за Романовським-Ґімзою. Активність каталази визначали спектрофотометричним методом. Спорідненість гемоглобіну до кисню вивчали спектрофотометричним методом у модифрікації Іванова побудовою кривих оксигенації. Вміст протопорфірину в цільній крові визначали, аналізуючи його спектри фрлюоресценції. Вміст нітрит-аніонів, сумарну активність NO-синтази й активність індуцибельної NO-синтази визначали спектрофотометричним методом.

Результати. За впливу фотобіомодуляційної терапії на здорових тварин відбувається зсув кривої дисоціації оксигемоглобіну ліворуч і зменшення $\mathrm{P}_{50}$, тоді як за дії опромінення на тварин із діабетом - зсув кривої праворуч та збільшення $\mathrm{P}_{50}$ порівняно зі значеннями у неопромінених тварин. За діабету вміст протопорфірину знижується порівняно з контролем, проте спостерігається тенденція до підвищення цього показника за дії фотобіомодуляційної терапії. За діабету відбувається зниження активності каталази у гемолізатах еритроцитів. Однак за дії фотобіомодуляційної терапії у щурів із діабетом спостерігається підвищення цього показника. Ми виявили достовірні зміни у лейкоцитарній формулі за дії фотобіомодуляційної терапії. Активність сумарної NO-синтази у лейкоцитах щурів із діабетом була вищою порівняно з групою здорових тварин, проте знижувалася за дії фотобіомодуляційної терапії. Ми виявили підвищення активності індуцибельної NO-синтази

ISSN 1996-4536 (print) • ISSN 2311-0783 (on-line) • Біологічні Студії / Studia Biologica • 2021 • Том 15 / № 3 • С. 3-16 
у лейкоцитах тварин із діабетом і в лейкоцитах здорових тварин за дії фотобіомодуляційної терапії. Встановлено зростання вмісту $\mathrm{NO}_{2}^{-}$у лізатах лейкоцитів щурів з діабетом. За дії фротобіомодуляційної терапії вміст $\mathrm{NO}_{2}{ }^{-}$у щурів із діабетом достовірно знижувався.

Висновки. Фотобіомодуляційна терапія має коригуючу дію на систему крові за діабету, зокрема, покращує вивільнення кисню з молекул гемоглобіну і запобігає розвиткові гіпоксичних станів. Одночасно зі збільшенням насичення тканин киснем зниження активності NO-синтази та вмісту нітритів, а також підвищення активності каталази запобігає розвиткові оксидативно-нітративного стресу.

Ключові слова: цукровий діабет; фротобіомодуляційна терапія, гемоглобін, NO-синтаза 